\title{
生体影響紫外線 DUVの天気及び雲量・出現高さ・ 雲形に基づく天空状態別解析 \\ EVALUATION AND CHARACTERISTIC ANALYSIS OF THE DUV (DAMAGING ULTRA VIOLET) VALUE ACCORDING TO THE SKY CONDITION BASED ON WEATHER CLASSIFICATION, CLOUD AMOUNT, APPEARANCE HEIGHT AND CLOUD FORM
}

\author{
新 聖子*, 垂 水弘夫**, 久保 猛志** \\ Masako SHIN, Hiroo TARUMI and Takeshi KUBO
}

\begin{abstract}
The interest for the ultraviolet radiation of people is turned to not only quantitative increase by the ozone layer depletion but also effect on the human body. In order to understand the amount of ultraviolet radiation exposed in the daily life and to make an effective defense countermeasure, it becomes necessary to show the information on the ultraviolet radiation environment by regions, weather classification, seasons and time zones. In this study, the data of DUV value which is one of the biologically weighted ultraviolet radiation are analyzed and evaluated according to the sky conditions based on weather information, cloud amount, cloud appearance height and cloud form.
\end{abstract}

Keywords : Damaging Ultra Violet, Ultraviolet solar radiation, weather classification 生体影響紫外線 DUV, 紫外域日射, 天気分類

\section{1.はじめに}

オゾン層破壊による地上到達紫外域日射量の增大への㲘念だけで なく，紫外域日射が及ぼす生体作用に対する人々の関心が高まって きている。わが国においても，2003 年 6 月に，紫外線保健指導マ二 ユアル 1) が環境省より発行されるなど，柴外線による健康影響及び 防御一の理解促進のための動きが見られる。日常生活で浴びる紫外 域日射量を理解し, 有効な防御策を施すためにも, 地域や天候, 季 節や時間帯による紫外域日射環境の情報を提示する必要がある。

筆者らは，紫外域日射による生体影響を数値的に評価するために， 紫外域日射に関する分光観測值注 1) と生体作用の重み付け係数を乗 じて波長積算するごとで算定される, 生体影響紫外線 DUV 注2)を用 いて地域・季節特性解析を行っできた。既報 ${ }^{2)}$ ５)では, 生体影響 紫外線 DUV の時別特性を明らかにすることを目的として，金沢の 晴天日における紫外域日射分光観測データを中心に，他の気象観測 データである日射量や紫外域日射の全量観測值（UV-A，UV-B）な どと対比させながら, 季節変化も含めて解析した。本報では DUV に関する時別特性解析を, 札幌, つくば, 鹿児島, 那羁を加え 5 地
域に展開し，地域による特徵を明らかにしていくこと，さらに，睛 天日だけでなく雲の存在する日に注目した天空状態別の紫外域日射 環境を明らかにすることを目的とする。雲量・出現高さ・雲形を分 類項目とし，雲の出現状況から天空状態を識別した場合の，DUV 值 による紫外域日射環境の相違を地域・月ごとに提示する。

紫外域日射について天空状態を加味した解析を行なった研究とし ては，佐々木 ${ }^{6)}$ ，川西 》などによるものがあるが，晴天空の放射輝 度を解析対象としている。本研究では, 水平面観測值を扱い, 人体 皮慮細胞中の DNAへの作用スペクトルを考虑した指標である DUV . を軸に検討している点に特色がある。

解析に用いる柴外域日射分光観測値は, 1990 年以降 Brewer 観測 機を設置した，気象台 4 地点及び金沢工業大学で観測された全蓄積 データ注3)，文解8) である。入手した分光観測值を全て，生体影響紫外 線 DUVに変換し，特性解析に用いることとしている。天空状態を 分類するための気象デー夕は, 各地域とも同期間の地上気象観測原 簿 9を入手し, 使用する。気象データからは, 昼間天気概況及び 3 時間毎の時別天気及び雲の出現状況を示す項目を抽出して用いる。

\footnotetext{
* 金沢工業大学大学院建築学専攻 大学院生 $\cdot$ 修士 (工学) Graduate Student, Dept. of Architecture, Kanazawa Institute of Technology,

** 金沢工業大学建築系 教授・工博 M. Eng. Prof., Division of Architecture, Kanazawa Institute of Technology, Dr. Eng.
} 
解析の流れとしては，地域・月毎の紫外域日射環境の日変動の相 違を知るために，まず，晴天日におうける DUV 值の変動特性につい て明らかにし，次に毎時の気象データに基づき天空状態別の DUV 值の算定と特性解析を行っていくこととする。最初に晴天日の值を 明確にしておくことで，天空の状態別に算定した DUV 值との比較 解析を行うことが可能となり，紫外域日射環境の相対的な関保を提 示することが出来る。

\section{2. 天気及び零の出現状況による天空状態の分穎について}

晴天日における DUV 日変動解析では，5地域の 1990 年以降の全 蓄積データの中から，睛天日を条件として抽出した時別值データを 解析対象とする。解析対象日の抽出過程と条件は次のとおりである。

1)地上気象観測原簿に記載されている 6 18 時の天気概況に「晴」 の表記が含まれている日。

2）日変動図を作成したとき, 経時変化に雲の存在の影響と思われ る急激な減衰が見られないこと（正午付近をピークとして，午前

と午後になめらかな数值の上昇と下降が認められる日）。 以上の条件で抽出したデータを用いて，月ごとに DUV 時別值によ る日変動図を作成する。月別該当 データ数を表 1 に示す。

天空状態別の DUV 算定では, 時刻別に 9 時, 12 時, 15 時の値に 注目し, 該当時刻の気象データに 基づき分類・整理することで，各 天空状態の紫外線量の比較を行な う。天空状態は，1）天気による分 類と，2）雲の出現状況の組み合わ せ毎に分類する。

また，用いる評価指標の DUV 值は，紫外域日射の人体における 許容被照時間数注 4) に換算可能な 值であることから，値の大小関倸 だけでなく，長短関係という比較 的理解しやすい時間数指標によっ てもまた，紫外域日射環境の相違 について表現することとした。

天空状態は, 雲量及び出現高さ に関する天気と降水の有無を考慮 し, 代表的な 5 種の天気注 5 )，「快 晴」,「晴」,「薄最」,「薷」,

「雨」に分類する方法と，雲の出 現状況による分類を行う。天気の 別による相違の大概を把握した上 で,より詳細な雲の出現状況（雲 量, 出現高さ，雲形 ${ }^{10)}$ ) 注6)別に DUV の推定を行ない天空状態別 紫外域日射環境の評価を行なうこ ととする。

なお，任意時刻の天空状態は， 複数の種類の雲の出現により構成
されている場合もある。その場合は, 出現している個々の雲の中で, 最も広い範囲で空を占めている雲形を天空状態判別のための分類要 素とした。

\section{3. 垉域・月ごとの時刻別平均 DUV 值算定結㛱}

\section{1 暗天日における DUV 日变動解析}

DUV 時別值による変化特性を明瞭に把握するために, 雲の影響が 小さい晴天日のデータから，時系列の変動特性を把握する必要があ る。前項で示した抽出課程を経て得られたデータを地域・月別に整 理したものが図 1（1）〜（5）である。夏季正午付近に現れる最大 DUV 值は低緯度地域ほど高くなり，夏季と冬季とでは，各地域とも $0.04 \mathrm{~W} / \mathrm{m}^{2}$ 前後の季節差が見られる。また，金沢における DUV の時 別変動について解析した前報 ${ }^{5)}$ で一部報告したように, DUVの日変

表 1 解析対象データの地域·月別日数(単位:日)

\begin{tabular}{l|rrrrrrrrrrrrrr}
\hline & 1 月 & 2 月 & 3 月 & 4 月 & 5 月 & 6 月 & 7月 & 8 月 & 9月 & 10 月 & 11 月 & 12 月 & 計 \\
\hline 札幌 & 22 & 26 & 28 & 47 & 49 & 49 & 34 & 40 & 29 & 46 & 29 & 21 & 420 \\
\hline 金沢 & 1 & 2 & 6 & 11 & 6 & 1 & 3 & 8 & 4 & 11 & 12 & 3 & 68 \\
\hline つくば & 152 & 99 & 70 & 62 & 47 & 17 & 28 & 23 & 24 & 60 & 95 & 137 & 814 \\
\hline 鹿児島 & 53 & 54 & 48 & 43 & 42 & 4 & 15 & 26 & 40 & 61 & 86 & 80 & 552 \\
\hline 那覇 & 13 & 17 & 14 & 20 & 23 & 15 & 14 & 29 & 40 & 42 & 27 & 34 & 288 \\
\hline
\end{tabular}

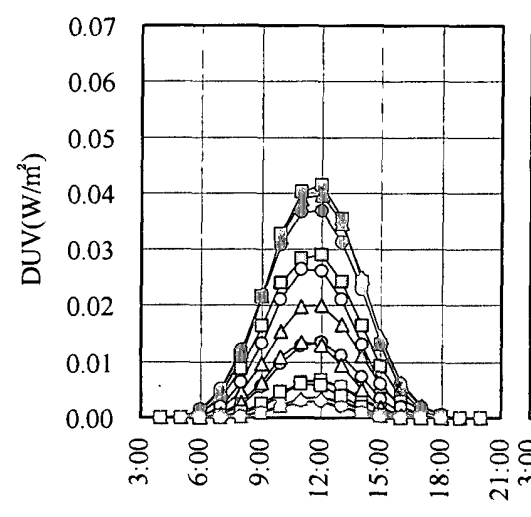

（1）札幌

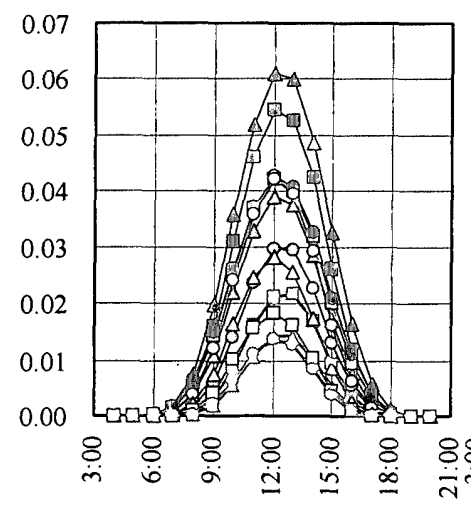

（4）鹿児島

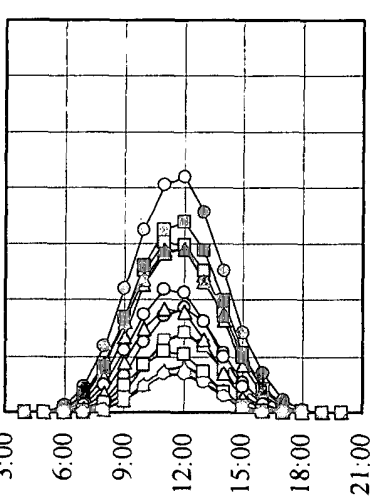

（2）金沢

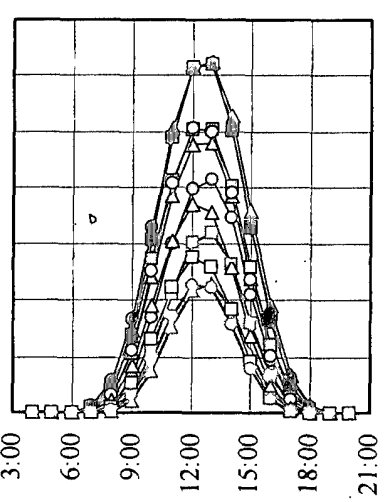

（5）那覇
図 1 晆天日の地域·月別 DUV 日変動

表 2 日穦算值に対するDUV及び日射時別値の割合の比較(金沢、単位:\%)

\begin{tabular}{|c|c|c|c|c|c|c|c|c|c|c|c|c|c|}
\hline & & 1月 & 2月 & 3月 & 4月 & 5月 & 6月 & 7月 & 8月 & 9月 & 10月 & 11月 & 12月 \\
\hline \multirow{2}{*}{ DUV } & 12時 $* 1$ & 23.5 & 22.6 & 20.5 & 18.9 & 17.3 & 17.6 & 17.4 & 18.4 & 19.4 & 20.5 & 21.6 & 22.7 \\
\hline & $10 \sim 14$ 時 $* 2$ & 17.7 & 15.8 & 14.1 & 13.2 & 12.6 & 12.1 & 12.5 & 13.1 & 13.9 & 15.1 & 16.1 & 17.4 \\
\hline \multirow{2}{*}{$\begin{array}{c}\text { 全天 } \\
\text { 日射量 }\end{array}$} & 12時 & 90.1 & 86.2 & 82.7 & 78.0 & 74.1 & 73.6 & 73.4 & 76.5 & 79.0 & 82.1 & 84.3 & 88.1 \\
\hline & $10 \sim 14$ 時 & 76.8 & 70.6 & 65.1 & 61.4 & 58.6 & 56.5 & 58.8 & 60.8 & 64.2 & 69.2 & 72.4 & 77.3 \\
\hline
\end{tabular}


動は全天日射注 7)に比べ, 正午までの立ち上がりが遅く, 夕方にか けての減衰が速やかであることに特徴がある注8)。日射日変動との比 較として, 毎正時の日射量データが得られる金沢について, 日積算 值に占める DUV 及び日射時別值の比率を月毎に算定し, 表 2 に示 した。尚，気象庁で公表されている日射量は，毎正時の瞬間値では なく, 前 1 時間の積算值であることから, 金沢を除く 4 地域では, 概算となるため，金沢での算出結果から考察することとした。DUV 值は, 正午の值で $17.3 \sim 23.5 \%, 10$ 時から 14 時の積算量では, 夏 季に 1 日の照射量の約 70〜80\%を，冬季には約 $90 \%$ を占めていた。 一方, 全天日射量では, 正午の值で $12.1 \sim 17.7 \%, 10$ 時から 14 時 の積算量では, 夏季に約 $60 \%$, 冬季で $80 \%$ 弱と DUV 值の正午付近 における日積算値に対する量の割合の高さが示された。

図 2 は, DUV 時別值の変動パターンを地域ごとに把握するために, 図 1（1）〜（5）の時別平均值について，正午の值を基準（1.0）と した比率を求めたものである。札幌・金沢・つくばの 3 地点では 11 〜12 時に, 鹿児島・那覇では 12〜13 時の時間帯にDUV 值はピーク を迎え，正午を挟んだ午前と午後とでは地域によって紫外域日射量 は異なることが確認される。これは，日本標準時である明石の東経 135 度を境に, 南中時刻が地域によって異なるためである。しかし, 最大 DUV 值を迎える時間帯を中心に増加・減少の率を結んだ折れ 線グラフの形自体は, 札幌, 那覇を問わず, 各地域ともほぼ同じ様 であり，日中の紫外域日射量のピーク時を挟んだ前後の時刻毎の増 加・減少の割合については地域による差の小さいことが明らかとな った。

\section{2 天気 5 分類による時別 DUV 值の提示}

天空の状態を簡単に表現する方法として，天気がある。そこで， 時別 DUV 值を気象データに基づき天気毎に 5 分類を行い，地域・ 月別に平均値を算定し, 表 3 に整理した。天気・月別の値のばらつ きを示すために, 12 時の値に関して変動係数も併せて表示した。表 中の網掛け部分は, 紫外域日射に関する許容被照時間数に換算した 際の階級表示であり，15 分以内（DUV 值で $0.033 \mathrm{~W} / \mathrm{m}^{2}$ 以上），15 $\sim 30$ 分 $\left(0.017 \mathrm{~W} / \mathrm{m}^{2}\right.$ 以上, $0.033 \mathrm{~W} / \mathrm{m}^{2}$ 未満), そして 30 分 $\sim 60$ 分 $(0.008$ $\mathrm{W} / \mathrm{m}^{2}$ 以上， $0.017 \mathrm{~W} / \mathrm{m}^{2}$ 末満）の 3 ランクの階級を設定した。このラ ンク設定にあたっては， 60 進の時間数として分かり易いこと $(60$ 分, 30 分, 15 分)，最短の許容被照時間数が 10 分程度であること, エネルギー量としての DUV 值で見た場合にも倍数に近い関係にな っていること，などを考虑した。全体的な特徵として，「快晴」，

「晴」，「薄量」，「睤」，「雨」の順に，DUV 值が低下寸る傾 向が見てとれる。また，変動係数は雲の様々な出現状況の影響を受 け，ほぼこの天気の順に大きくなっている。

また，表中の「比率」は 12 時の快晴時の DUV 值を基準（1.0）と した各值の比を算定し，示したものであり，「割合」は各地域にお ける夫々の天気の出現傾向を示したものである。「快晴」の出現割 合の高いのはつくばであり，「晴」では那醐が各時刻とも約 $40 \%$ の 高い出現割合を示している。太平洋側のつくばでは雲の少ない晴天 日が多く，那羁では四方を海に囲まれている地理的条件から比較的 雲が出現しやすく，天気分類で「晴」の出現頻度が高くなっている ものと考えられる。また，各地域とも「賏」の出現頻度が $30 \%$ 程度，

「雨」では $10 \%$ 強と同程度の值である。

12 時の札幌・金沢・つくば・鹿児島の DUV 値は「快晴」，「晴」，

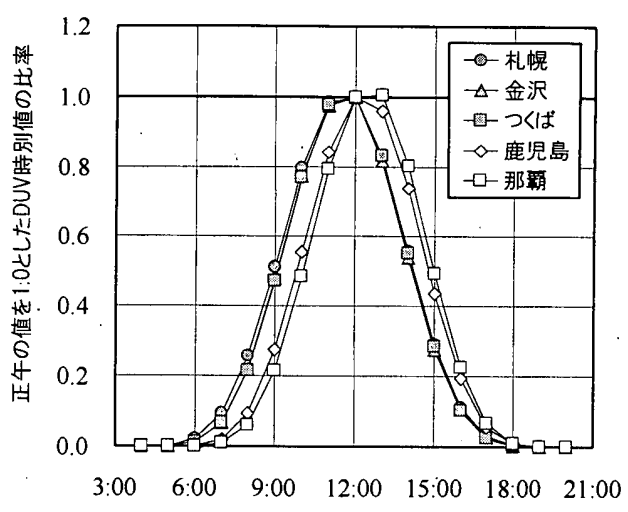

図 2 正午の值を基準(1.0)とした比率 ※ 図 1(1) (5) から作成

「薄墨」の順に $10 \%$ あるいは $5 \%$ 程度ずつ低下する様子が見られる が, 那覇では天気分類によらず同程度の值をとることが示された。

また, 雲の出現している天気に加え, 降水の有無による差異を示 すために「雨」の分類項目を設けてある。「雨」の值に注目すると， 「快晴」に対して $1 / 3$ 程度の值であり, 夏季においてはどの時刻の 值を見ても「眃」の $1 / 2$ 程度の值となっている。その中で最も大き い值をとったのは, 那羁 7 月の 12 時の $0.020 \mathrm{~W} / \mathrm{m}^{2}$ であり,この值は 那羁の夏季「快晴」9 時の DUV 值よりも高く, 札幌の夏季・「快晴」 9 時の值とほぼ同じであった。「雨」では「量」天時よりも DUV 值 は低くなるものの, やはり低緯度地域においては高い值をとり, 許 容被照時間数ランクで見ても 30 . 分以内となる柴外線環境であるこ とが示された。

表中に示した比率で比較すると,「快晴」で 9 時の值は 12 時に比 べ, 高緯度地域では約 $1 / 2$, 鹿児島・那覇で $1 / 4 \sim 1 / 5$ となっている のに対し，15 時で見ると比率值は逆転している。すなわち，15 時の 值は 12 時に比べ，札幌・金沢・うくばで約 $1 / 4$ ，鹿児島・那覇で $2 / 5$ 〜1/2 程度となっているのである。

次に 9 時, 12 時, 15 時と時刻別に值を見ていくこととする。まず, 9 時の時間帯について見ると, 最も高いDUV值を示すのは, 金沢・ 6 月の「快晴」時の $0.023 \mathrm{~W} / \mathrm{m}^{2} て ゙$, 次いで, 札㨪の $0.022 \mathrm{~W} / \mathrm{m}^{2}$, つく ばの $0.021 \mathrm{~W} / \mathrm{m}^{2}$ と, 高緯度 3 地域の晴天時で鹿児島・那醐の值を上 回っている。また, 許容被照時間数が 30 分以内となるランクは, 那 覇を除く 4 地域の夏季で該当しており，夏季においては那羁よりも 他の 4 地域の方が生体影響の大きい紫外線環境にあることが示され ている。

次に 12 時の值に注目すると, この時間帯では, 那覇の 8 月「快晴」 が $0.058 \mathrm{~W} / \mathrm{m}^{2}$ と最も高く, 9 時の同天気の值の 4 倍程度にまで上昇し ている。また, 12 時に許容被照時間数が 15 分以内となるランクの DUV 值は，那羁から札幌まで全地域に広がっている。しかし，金沢 とつくばの高緯度地域では，夏季を中心とした「快晴」，「晴」，

「薄睡」がこれに該当するのに対し, 鹿児島及び那羁では該当範囲 が広がる傾向が顕著である。鹿児島では 4 月や 9 月, 那羁では 3 月 や10月までも，このランクに含まれ，両地域の夏季では「䝮」であ ってもこのランクとなっている。正午付近の生体影響紫外線につい ては緯度の高低にかかわらず，全国的に夏季を中心とした好天下で 防御対策を要するとともに, 低緯度地域では, 春, 秋を含む季節や 睤天時の活動においても，晴天時と同等の防御策を講ずる必要があ 


\section{ると言えよう。}

更に 15 時の時間帯につい

て見ると，各地域の 15 時にお ける最大值は, 札幌とつくば は 7 月「快晴」の $0.015 \mathrm{~W} / \mathrm{m}^{2}$, 金沢では 6 月の「快晴」にお ける $0.014 \mathrm{~W} / \mathrm{m}^{2}$, 同じく鹿児 島と那羁でも 6 月の「快晴」 で夫々 $0.030 \mathrm{~W} / \mathrm{m}^{2}, \quad 0.034 \mathrm{~W} / \mathrm{m}^{2}$ となっている。低緯度地域の 2 地域が他の 3 地域の 2 倍以 上の值となっているほか, DUV 值のランクでは那羁に おいて許容被照時間数で 15 分以内の月や天候があり, 依 然として防御対策の必要性の 高い時間帯であることが判る。

\section{4. 天空状態別 DUV 谊の推定} 4. 1 各地域における天空 状態の出現傾向

天空状態は, 雲の出現状況 によって多種多様である。前 項では，雲量を中心とする天 気概況によって天空状態の分 類を行ったが，同一天気であ っても, 幅広い数值のデータ が含まれてしまう場合がある。 特に天気「晴」には, 雲量 2 〜8 の状態が含まれるため, 雲の出現状況によって更にデ 一夕を分類し, 解析を行う必 要があると思われる。また，

「雨」においても同様で，天 気概況では降水の有無により 判断されているため, 雲の状 況によって，紫外線量は異な るものと推測される。そこで, 気象データ中の雲の出現状況 を表す項目を用いて，より実 態に近い天空状態別 DUV の 算定を行なうこととした。

図 3 は，5地域に扔ける出 現傾向を把握するために, 出現高さ（CL：下層雲, CM : 中層雲, $\mathrm{CH}$ : 上層雲) による出現率を月ごとに求めた結果であり，12 時の 出現雲について示している。

全体的に下層雲の出現率が高くなっているが，これは一般的によく 見られる雲である瀆雲 $\mathrm{Cu}$ の出現が大半を占めているためである。 CH の出現率が最も高いのは, 金沢における夏季で, CMの出現率が 高くなるのは低緯度地域の春季であることが読み取れる。札幌では,

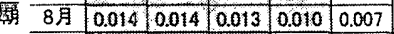

表 3 時刻·天気別 DUV 值算定結果一覧 $\left(\right.$ 単位: $\left.\mathrm{W} / \mathrm{m}^{2}\right)$

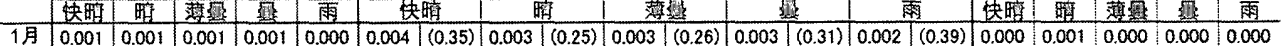

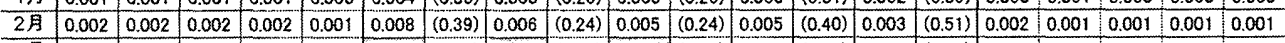

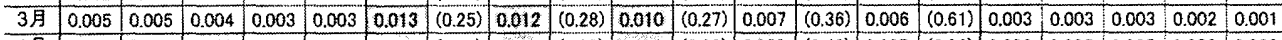

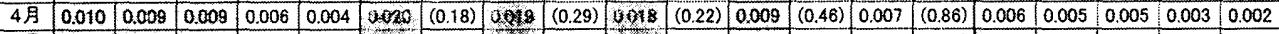

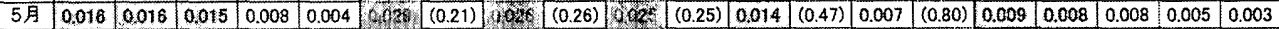

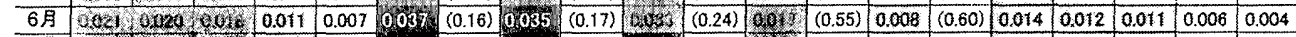

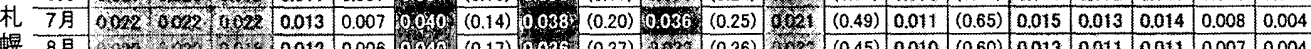

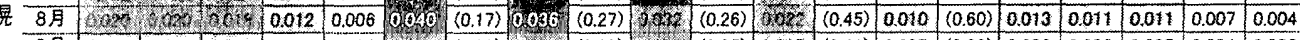

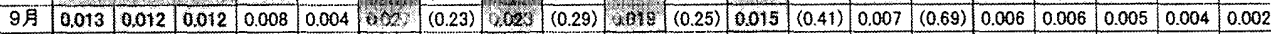
\begin{tabular}{c|c|c|c|c|c|c|c|c|c|c|c|c|c|c|c|c|c|c|c|c|}
\hline 10月 & 0.007 & 0.006 & 0.006 & 0.004 & 0.002 & 0.013 & $(0.30)$ & 0.011 & $(0.37)$ & 0.012 & $(0.29)$ & 0.007 & $(0.49)$ & 0.004 & $(0.67)$ & 0.002 & 0.002 & 0.002 & 0.001 & 0.001 \\
\hline
\end{tabular}

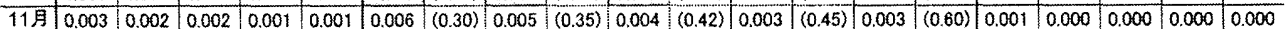

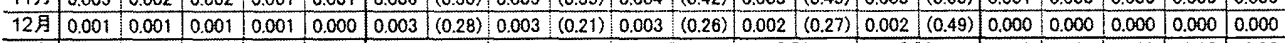

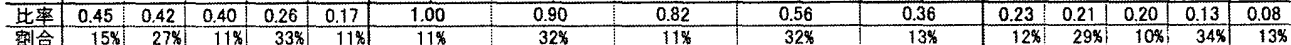

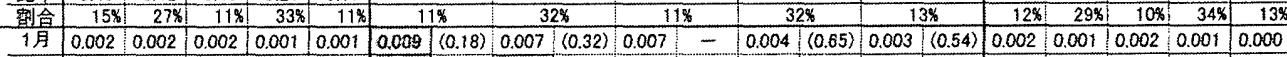

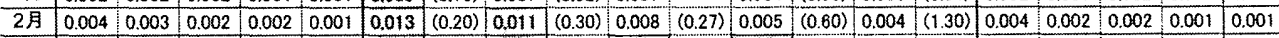

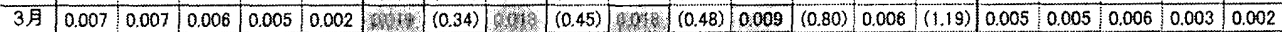

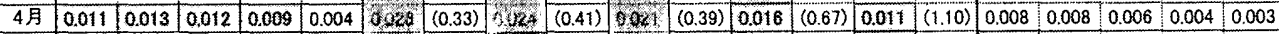

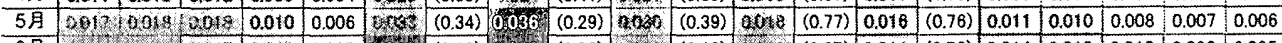

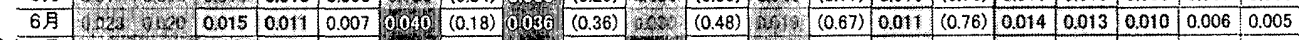

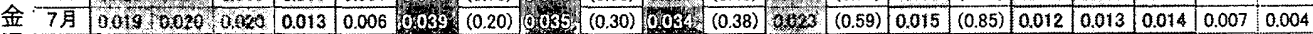

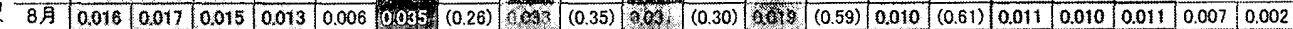

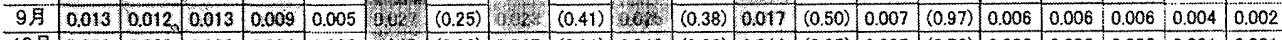

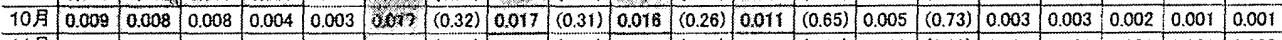

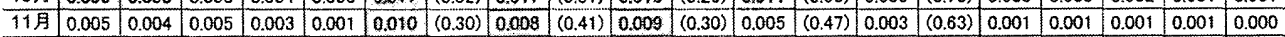

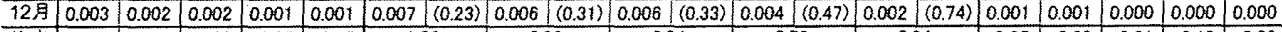

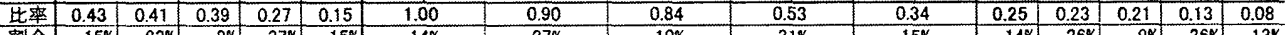

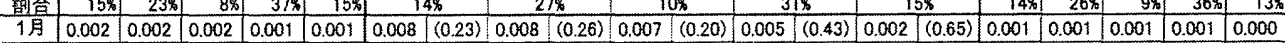

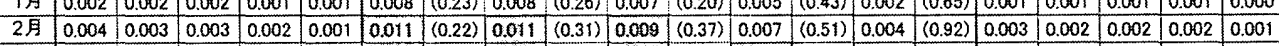

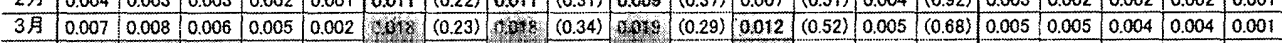

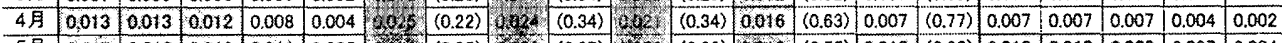

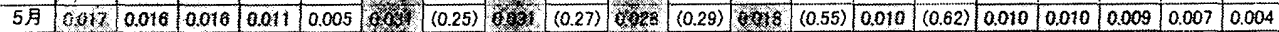

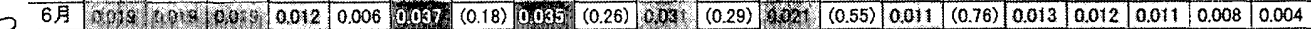

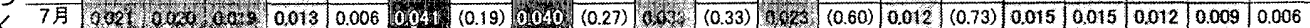

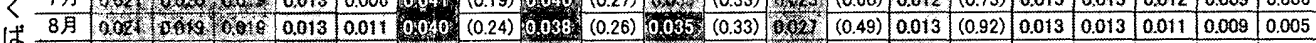

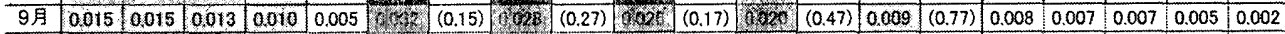
\begin{tabular}{c|c|c|c|c|c|c|c|c|c|c|c|c|c|c|c|c|c|c|c|c|c|}
\hline $10 月$ & 0.010 & 0.039 & 0.009 & 0.006 & 0.003 & 0.099 & $(0.23)$ & 0.045 & $(0.28)$ & 0.016 & $(0.31)$ & 0.012 & $(0.46)$ & 0.005 & $(0.85)$ & 0.003 & 0.003 & 0.003 & 0.002 & 0.001 \\
\hline
\end{tabular}

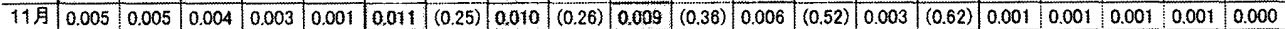

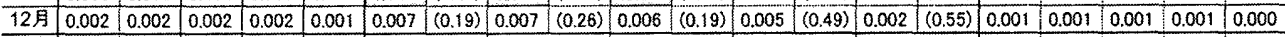

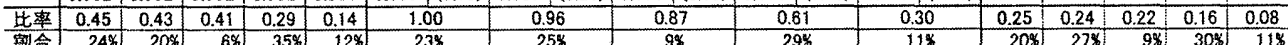

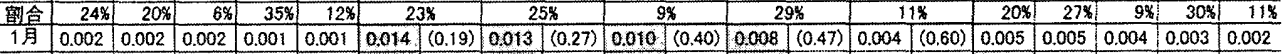

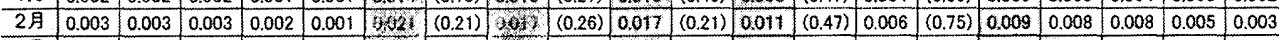

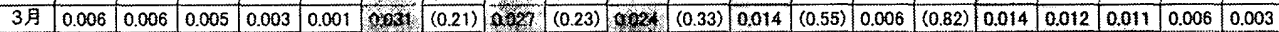

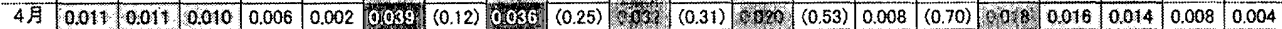

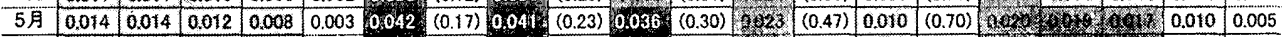

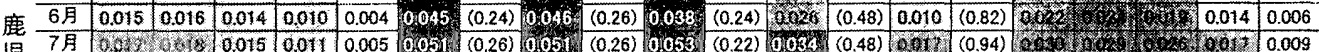

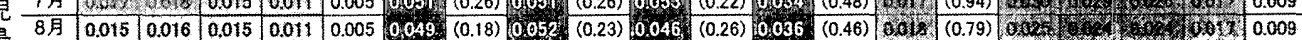

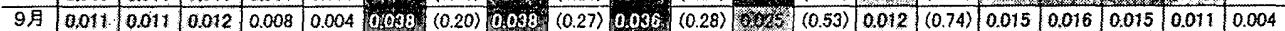

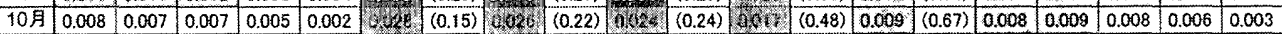

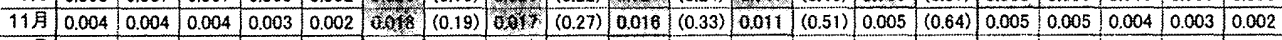

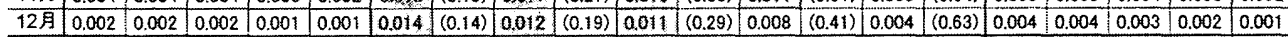

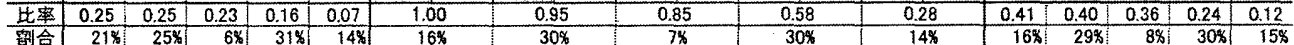

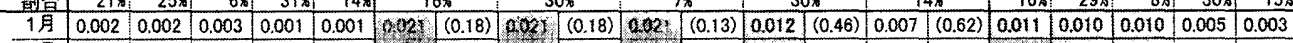

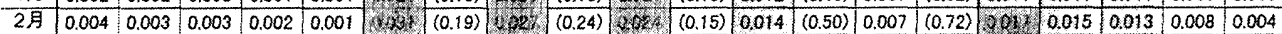

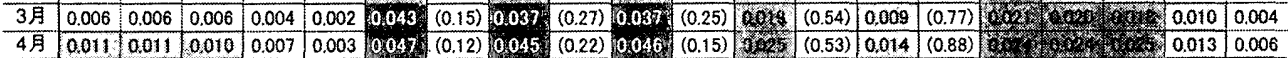

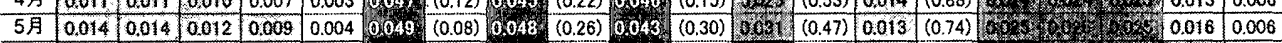

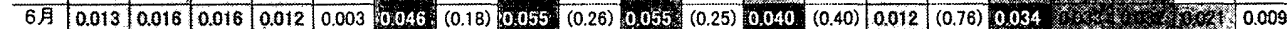

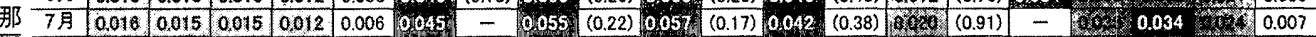

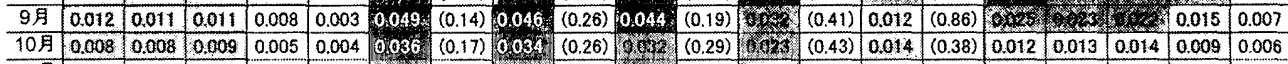

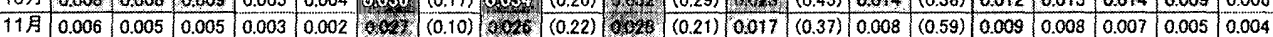

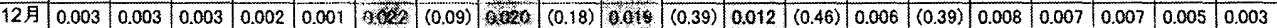

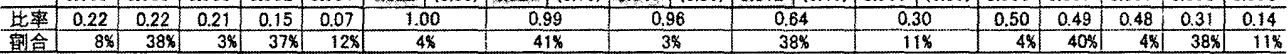

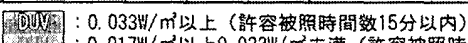

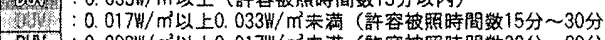

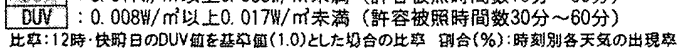

1 年を通して CL の出現率が多く，金沢では月毎の出現率が大きく 異なり，季節によって空模様は大きく変化している。っくばと鹿児 島では, 他地域と比べ $\mathrm{CH}$ 及び $\mathrm{CM}$ の出現率が高く, 季節間の出現 率の変動も少ない。那羁は, $\mathrm{CH}$ の出現率が低く, CL の出現率が高 く, CM に関しては夏季において低くなる傾向にある。以上，天空 状態を雲の出現高さのみから見ても, 地域・季節によって異なる特 徵が確認された。 


\section{2 雲の出現状況別 DUV 值の算定}

前項の結果を踏まえ， 12 時の時間帯を対象に，雲の出現状況に応 じた天空状態別の分類を行った。雲量及び天気，高さ，雲形を基に 天空状態別に算定した DUV を表 4 に示す。雲形は国際分類に基づ く 10 種の分類項目を設け，天気「晴」については，雲量で $2 \sim 4$ と 5〜8に分け, 表 3 同様, 許容被照時間数によるランク分けを施した。 本論文で取り上げることの出来る分光観測値の蓄積が，最大でも 10 年程度であるため, 雲量, 出現高さ, 雲形などを用いて分類した場 合，個々には充分なサンプルが得られないケースも生じるが，現時 点でも傾向を把握することが重要であると考え，解析を行ったもの である。

各地域における最大 DUV 值は 6〜8 月に現れ，その值は，札幌で

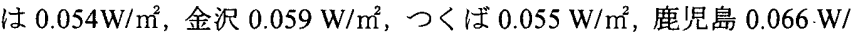
$\mathrm{m}^{2}$, 那羁 $0.063 \mathrm{~W} / \mathrm{m}^{2}$ であり, 表 1 の天気分類で見られた最大値より も高い值となった。その最大值をとる天空状態は，つくばでは「快 晴」時に下層雲が出現している状態であるが，他の 4 地域では「晴」 または「薄最」の天気で，上層雲が出現している状態であった。雲 の全く無い晴天時よりも，多少の雲や上層雲が出現している方が， 反射等の影響により地上到達紫外線量は増大するものと推察される。

全体的に見て，雲量 0〜1の場合，雲形によるDUV 值の差異は小 さく, 雲量 2 4 2 と 8の同じ雲形では冬季に開きが見られるもの の, 夏季には同程度の数值となっている。また, 雲量 9〜10では, 上層雲の出現時に, より高い DUV 值をとること, 中層雲の出現時 には, 各月の值が Ac (高積雲), As (高層雲), Ns (乱層雲, 主に 雨雲) の順に DUV 值が低くなる傾向にあることが全地域で見られ た。雲量 9〜10の下層雲の出現時に, Sc (層積雲) の值が夏季にお いて比較的高かったことから，灰色がかった雲の譬の日でも意外と 紫外線量が多いという認識を持つ必要があると言えよう。

夏季を中心に許容被照時間数が 15 分以内となる天空状態は, 札幌, 金沢，つくばにおいては，少ない雲量の天空状態から上層雲で雲量 9 10 の場合までであるが，鹿児島，那覇では中層・下層雲で雲量 9 〜10 の場合でも該当している。許容被照時間数 30 分以内となる月

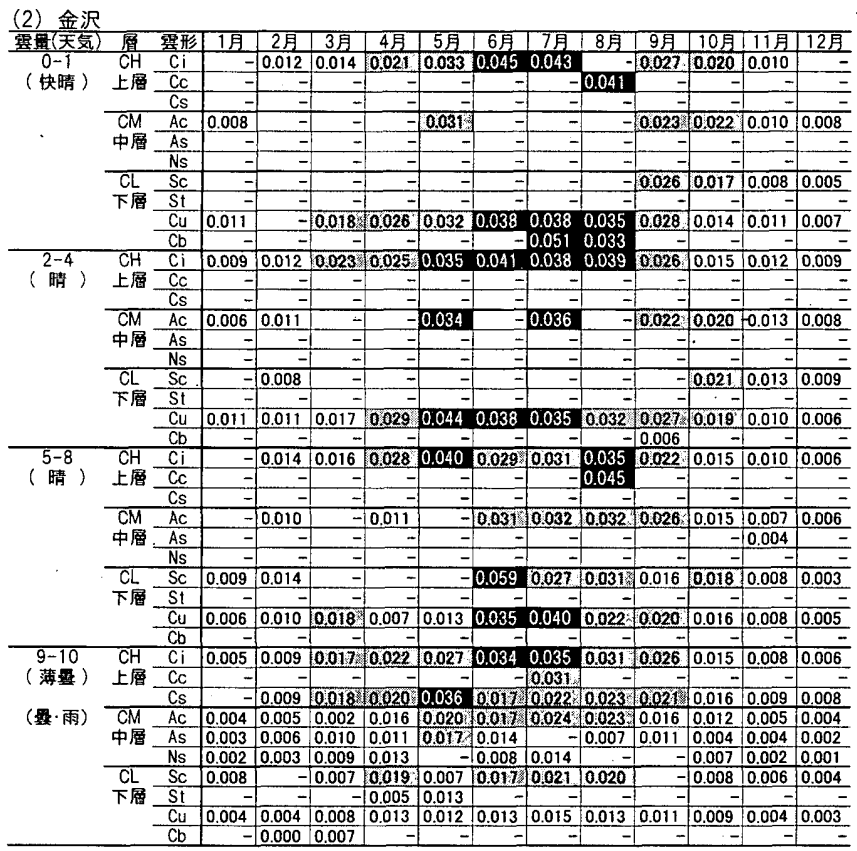

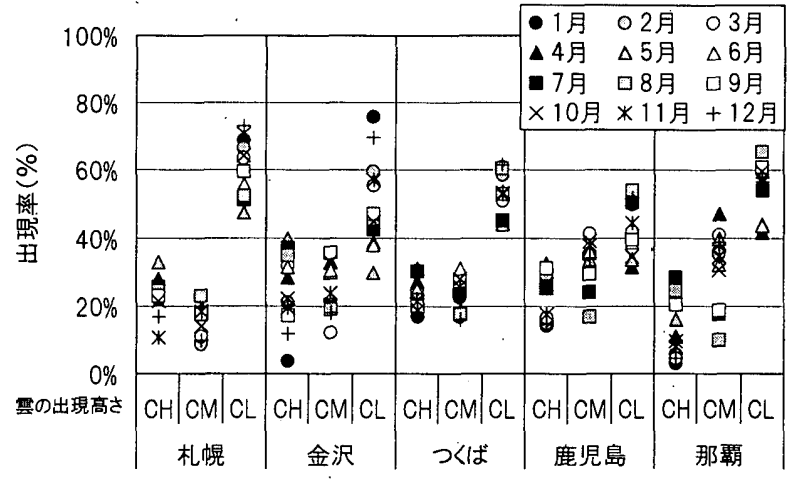

図 3 雲の出現高さ別出現割合

※ $\mathrm{CH}$ : 上層需, $\mathrm{CM}$ : 中層胥, $\mathrm{CH}$ : 下層雲

表 4 天空状態別 DUV 值算定結果及び許容被照時間数による紫外域日 射環境評価(単位: $W / \mathrm{m}^{2}$ )

(1) 札饾

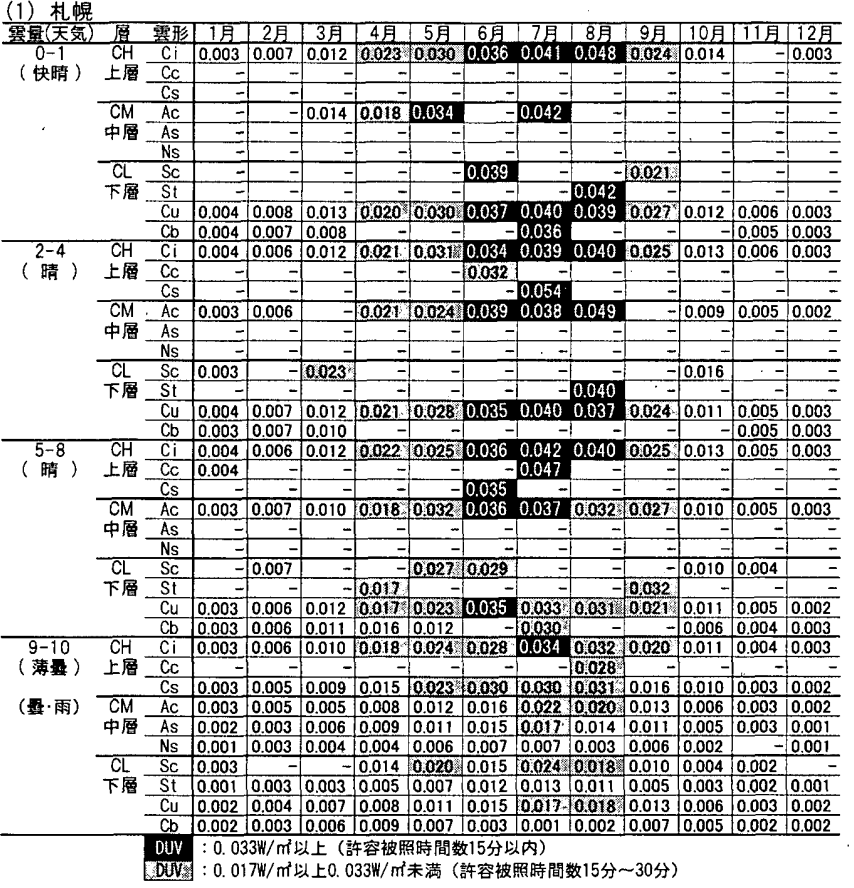

(3) 2 くば

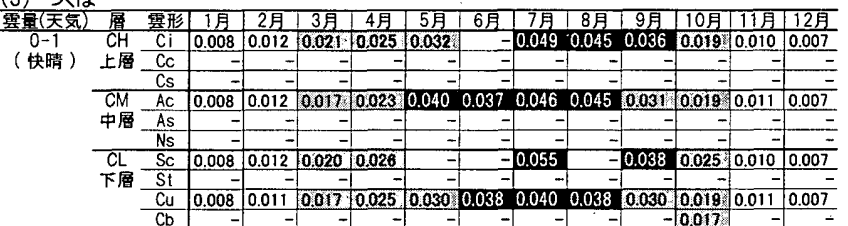

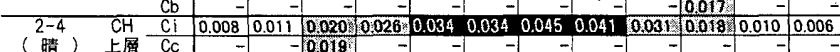

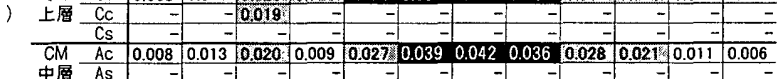

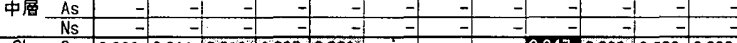

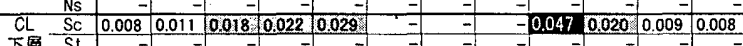

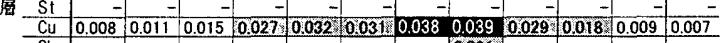

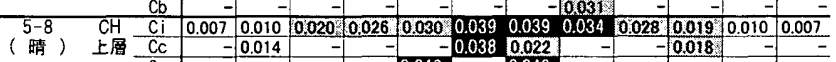

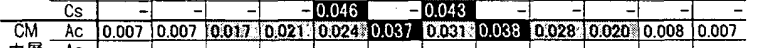
中層 $\mathrm{As}-\mathrm{As}$

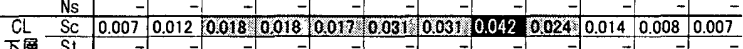

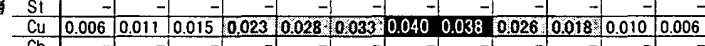

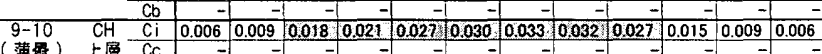

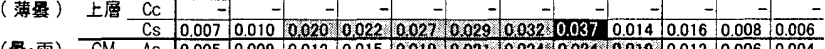

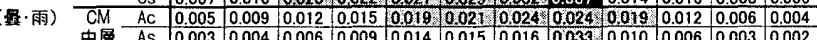

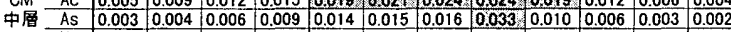

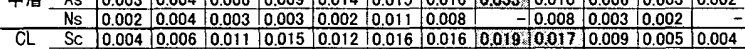

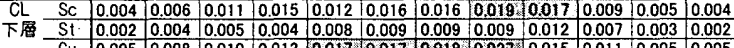


表 4 天空状態別 DUV 值算定結果及び許容被照時間数による紫外域日射環境評価(単位: $\mathrm{W} / \mathrm{m}^{2}$ )

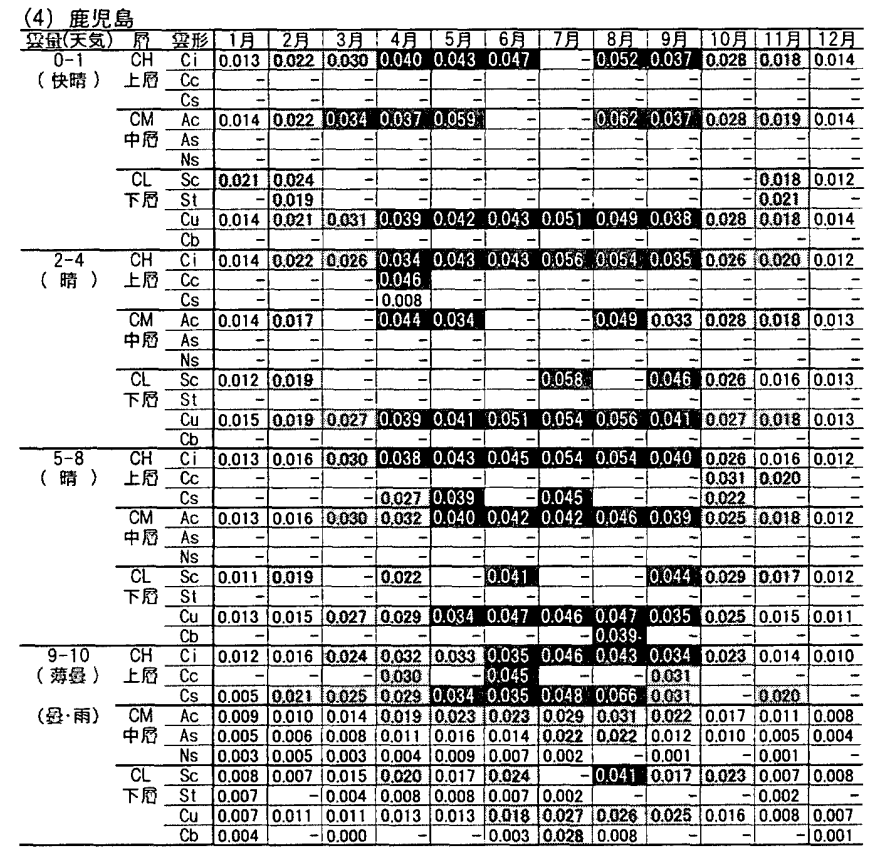

は，札幌では 4〜9月，金沢とつくばでは 3〜10月，鹿児島では冬季 2 ヶ月を除く 2 11月, 那羁では, 睤・雨天時を除く全ての場合が 該当し，低緯度地域ほど短い許容被照時間ランクの出現期間に広が りが見られた。また, 全体的な傾向として, 雲による DUV 值の減 衰は，積雲より層状雲，薄い雲より厚い雲において，一層大きくな ることが読み取れた。

\section{3 天空状態が及ほす DUV 及び日射量の減衰傾向について}

次に金沢を対象として, 時別天気に雲の出現状況を取り入れた代 表的な天空状態における DUV 值と日射量の減衰傾向について解析 を行った結果を記す。金沢における 12 時の全天日射量瞬間值主》は， 本学で観測された値を用いている。

図 4 に金沢（12 時）の天気・雲の出現状況別に算定した DUV 值 と日射量の月平均值を, 表 5 には 6 8月 3 ヶ月分の快晴時データを 基準とした各種天空状態下における DUV 值と日射量の比率を，数 值として掲げている。図4（1）及び（2）より，夫々の天空状態に おける月平均値の最大值を比較すると, 值の減衰は DUV で 0.040 W/ $\mathrm{m}^{2}$ から $0.013 \mathrm{~W} / \mathrm{m}^{2}$ への約 $68 \%$ の落ち込みであるのに対し，日射量は $962 \mathrm{~W} / \mathrm{m}^{2}$ から $231 \mathrm{~W} / \mathrm{m}^{2}$ までの $76 \%$ の低下が見られる。减衰率の相違 から，日射に対する紫外線量の割合は天空状態によって異なるもの と考えられ，さらに全天日射量に対するDUVの割合を算出し，図 4 （3）として図示した。その結果, 雲量が 8 以上の天気で「薄艮」よ り「曇」，そして「雨」の順で日射量に対する紫外域日射量の割合が 高くなることが示され，日射の減衰に比べて生体作用に関する紫外 線量の天空状態による減衰は小さいことが明らかとなった。また, 晴天時では，日射に対する割合が高くなる月は 6〜8月で，冬季とは $0.003 \%$ 程度の季節変動が見られ，「薄臱」、「量」、「雨」の順で季節 間の変動幅が大きくなることも示された。

表 5 の数値を読むと, 雲量により 2 分類した「晴」において, 雲 量 2〜4 では DUV, 日射とも「快晴」とほぼ変わらないが，雲量 5 〜8 では夫々 $15 \%$ 程度の低下が見られた。「薄曇」では, $\mathrm{Ci}$ (巻雲) と Cs (巻層雲) の比較を行ったところ, 同じ高度の雲であっても,
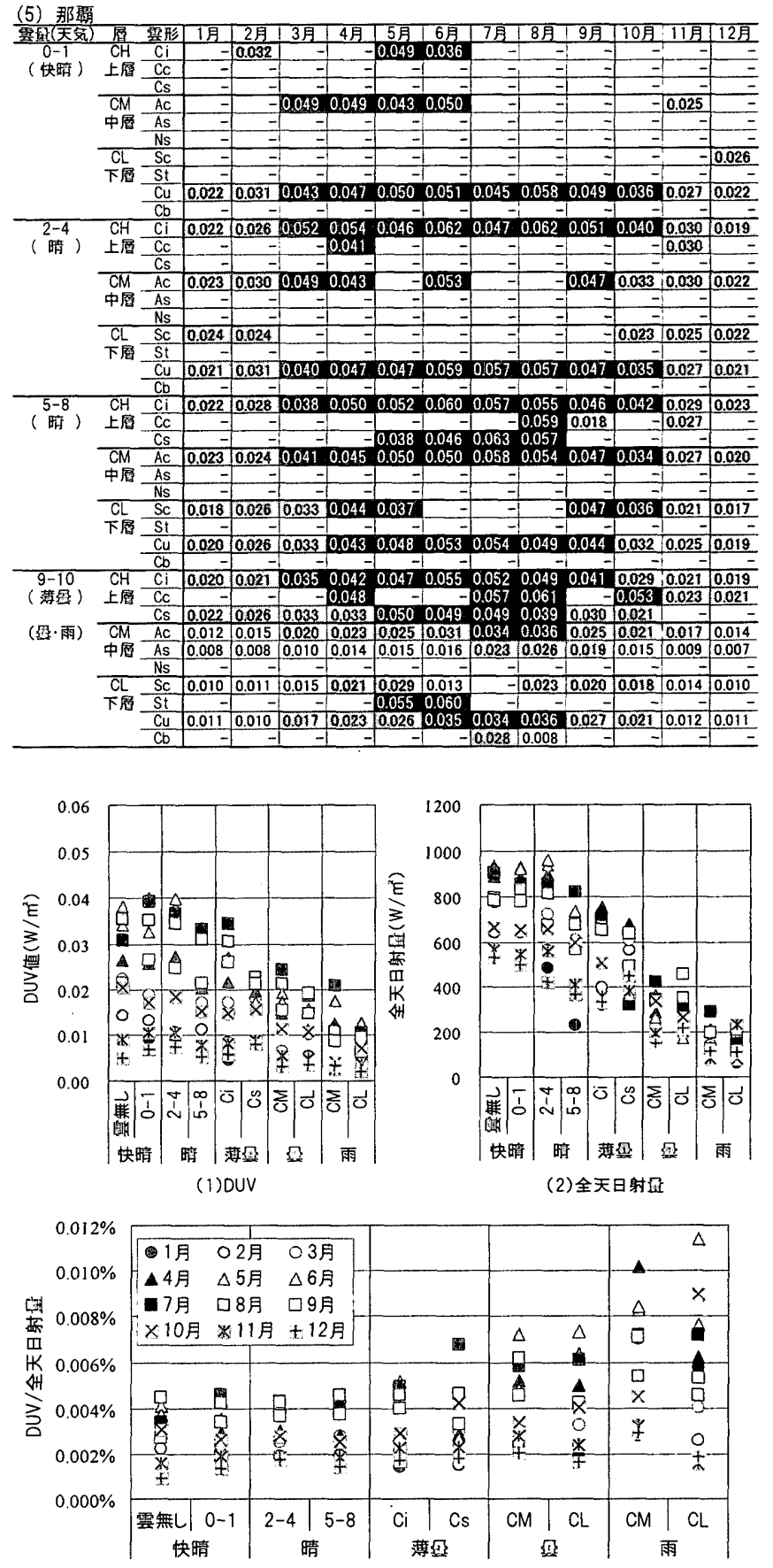

（3）全天日射量に対するDUVの割合

図 4 天気·雲の出現状態別 DUV と日射量(金沢 12 時)

表 5 快晴時を基準(1.00)とした各種天空状態におけるDUV 及び 全天日射量の比率

\begin{tabular}{|c|c|c|c|c|c|c|c|c|c|c|}
\hline & \multicolumn{2}{|c|}{ 快晴 } & \multicolumn{2}{|c|}{ 晴 } & \multicolumn{2}{|c|}{ 薄霓 } & \multicolumn{2}{|c|}{ 霓 } & \multirow{2}{*}{\multicolumn{2}{|c|}{ 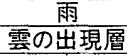 }} \\
\hline & 雲無し & 雲量 & 雲量 & 雲畏 & 雲形 & 雲形 & 雲の & 現䆏 & & \\
\hline & - & $0-1$ & $2-4$ & $5-8$ & $\mathrm{Ci}$ & $\overline{\mathrm{Cs}}$ & $\mathrm{CM}$ & $\mathrm{CL}$ & $\mathrm{CM}$ & $\mathrm{Cl}$ \\
\hline DUV & 0.88 & 1.00 & 0.97 & 0.85 & 0.87 & 0.54 & 0.55 & 0.43 & 0.37 & 0.27 \\
\hline 日射 & 1.00 & 1.00 & 1.00 & 0.86 & 0.78 & 0.55 & 0.43 & 0.34 & 0.24 & 0.19 \\
\hline$N$ & 4 & 51 & 59 & 73 & 42 & 6 & 60 & 55 & 21 & 25 \\
\hline
\end{tabular}

層状の雲の方が顕著な減衰が確認されるなど，DUV，日射とも雲形 による減衰傾向に相違が見られた。量」と「雨」では，CL（下層 雲) と CM (中層雲) の雲の出現層による比較を行った。その結果, 
CL と CMにおける DUV 值の比率に 1 割弱の差異が認められたこと から，DUVの減衰が顕著なのは，CLの方であることが数值レベル で示された。また DUV と日射の隇衰率にも1割弱の差が生じてお り, 曇天時の快晴時に対する紫外線の低下率は日射に比べて低いこ とも明らかとなった。以上，天気分類としては同じ天気に属してい ても，雲の出現状況によって紫外域を含む日射環境は異なることを 数値として明示したものである。

\section{5. まとめ}

本研究の成果を以下にまとめる。

1) 紫外域日射量の時刻变動特性を知るために, 全国 5 地域の晴天日 デ一タによるDUV 日変動図を作成した。その結果, 全天日射と比 較して朝夕よりも正午付近の数値の増大が著しいこと，9時よりも 15 時における地域差が大きいこと，さらに，各地域のピーク出現時 刻を挟む前後の時別増隇率の地域差は小さいこと，などが明らかと なった。

2) 時別DUV値に関して地域・月ごとに天気 5 分類を行い整理した。 その結果， 12 時の札幌・金沢・つくば・鹿児島では「快晴」,「晴」,

「薄最」の順に $10 \%$ あるいは $5 \%$ 程度ずつ低下する様子が見られる が，那羁では天気分類によらず同程度の值をとることが示された。 また，「曇」だけでなく「雨」においても，特に低緯度地域で相当量 の生体影響紫外線が存在することが確認された。

3) 天空状態を表す雲量, 雲の出現高さ, 雲形のマトリックスとして, 地域別・月別 DUV 值を提示した。数値の減衰は, 積雲より層状雲, 薄い雲より厚い雲で大きいという傾向を明らかにすることが出来た。 また, 雲の出現状況に基づく「晴」や「薄晨」の細分類において, その最大值が天気 5 分類の結果よりも大きいことから，雲の全く無 い晴天時よりも, 多少の雲や上層雲が出現している条件下において, 地上到達紫外線量は増大するものと推察された。

4) 天空状態によるDUV 值と全天日射量の快晴時に対する减衰傾向 を明らかにするために，金沢の 12 時の值を対象に解析を行った。そ の結果，同じ天空状態において快晴時に対するDUV と日射の減衰 率には差が生じ, 雲出現時において DUV 值の方が隇衰率は低いこ とが確認された。

今後は, 水平面だけでなく, 鉛直面や角度・方位を持った斜面に入 射する紫外域日射量についても観測・解析を実施し，人体と紫外線 環境に関する具体的な照射モデルの提示に向けて検討を進める予定 である。

\section{注 釈}

1）Brewer 紫外域日射分光観測機 2) -5)。カナダの SCI-TEC 社製。観測波長帯 は290〜325nmであり，0.5nm 刻みで分光測定を実施。

2）分光観測を行った各波長の UV 值に，皮膚細胞中の DNA への波長別影響 割合を考應した次式で示されるアクション・スペクトル (AS(L), L は波長) を乗じ，集計することによって求められる值である2 2 一
AS $(\mathrm{L})=1-0.36\{(\mathrm{~L}-270) / 20\}^{1.64}$
$290 \leqq L \leqq 300 \mathrm{~nm}$
AS $(\mathrm{L})=0.3 \times 0.7356^{(\mathrm{L}-300)}+10^{(2-0.0163 \mathrm{~L})}$
$300<\mathrm{L} \leqq 325 \mathrm{~nm}$

3）札幌，つくば，鹿児島，那羁は気象台で観測され，気象業務支援センター を通じて公開されているデータ ${ }^{8)}$ を，金沢は金沢工業大学における観測值 を用いる。地点の詳細及び使用期間は表 A に示す通りである。

4) 許容被照時間数については, 既報 ${ }^{4)}$ に詳しいが, DUVによる被曝基準值(30J/ $\left.\mathrm{m}^{2}\right)^{10)}$ を用いることで算定可能な時間数のことである。

許容被照時間数 $(\mathrm{sec})=30\left(\mathrm{~J} / \mathrm{m}^{2}\right) / \mathrm{DUV}$ の時別値 $\left(\mathrm{W} / \mathrm{m}^{2}\right)$

この DUV に関する許容被曝量 $30 \mathrm{~J} / \mathrm{m}^{2}$ は, ACGIH（米国政府産業衛生学者
会議)が皮處細胞中の DNA の紫外放射吸収，眼の白内障への作用など, 種々 の人体作用スペクトルの外縁線として定め, WHO によって採用されている DUV の波長帯域別の重み付けの数值に, 分光観測されだ紫外域日射量を乗 じ，それを時間積分した被曝量の許容值として表わされている。スキンタイ プ1 に属する白色人種の感受性の高い人を基準に定められている数值で ある。労働環境だけでなく，一般の環境にも適用される。現在のところ日 本人や黄色人種に関する基準許容被曝量は公表されていないので，本研究 では, この基準值を用いて解析を行った。

5) 気象データ中の 3 時間毎に気象庁天気種類表で記载されている「天気」の 項目を採用している。分類項目は表 $\mathrm{B}$ に示す 5 種の天気とした。分類に用 いた下記の天気の他に,「煙霧」、「砂じんあらし」,「地ふぶき」、「霧」,「霧 雨」,「みぞれ」、雪」,「あられ」,「ひ上う」,「雷」がある11。

6）雲は高度により上層雲，中層雲，下層雲に分けられ，巻雲・層雲・積雲な ど 10 種類の雲形に分類される ${ }^{11}$ 。この 10 種雲形は 1956 年版の国際雲図帖 の分類に従うものである。

上層雲 $\mathrm{CH}:$ 巻雲 $\mathrm{Ci}$, 巻積雲 $\mathrm{Cc}$, 巻層雲 $\mathrm{Cs}$

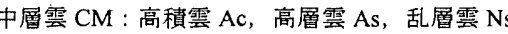

下層雲 $\mathrm{CL}$ ：層積雲 $\mathrm{Sc}$ ，層雲 $\mathrm{St}$ ，樌雲 $\mathrm{Cu}$ ，積乱雲 $\mathrm{Cb}$

7)全天日射計は英弘精機株式会社製の MS-801 で, 測定波長域は 300 2800nm。

8）図 A に既報 5）で提示した值を用いて，12 時を基準とした DUV 及び全天 日射時別値による日変動の相違を示す。DUVの方がより急峻な変動を見せ ている。

\begin{tabular}{|c|c|c|c|c|c|}
\hline 地域 & 緯度 & 経度 & 解析対象データ & 高度(m) & 設置機関 \\
\hline 札幌 & $43^{\circ} 03^{\prime}$ & \begin{tabular}{l|l}
$\mathrm{N} / 141^{\circ} 20^{\prime}$ \\
\end{tabular} & \begin{tabular}{l|l|l|l}
$\mathrm{E}$ & $1991 \sim 2000.12$ \\
\end{tabular} & 25.7 & 気象台 \\
\hline 金沢 & $36^{\circ} 31^{\prime}$ & \begin{tabular}{l|l}
$N$ & $136^{\circ} 37^{\prime}$ \\
\end{tabular} & \begin{tabular}{l|l}
$E$ & $1997.3 \sim 2002.9$ \\
\end{tabular} & 42.5 & 金沢工童大学 \\
\hline Х〈は（館野) & $36^{\circ} 03^{\prime}$ & \begin{tabular}{l|l}
$\mathrm{N}$ & $140^{\circ} 08^{\prime}$ \\
\end{tabular} & \begin{tabular}{l|l}
$\mathrm{E}$ & $1990.1 \sim 2000.12$ \\
\end{tabular} & 30.5 & 気象台 \\
\hline 鹿児島 & $31^{\circ} 33^{\prime}$ & \begin{tabular}{l|l}
$\mathrm{N}$ & $130^{\circ} 33^{\prime}$ \\
\end{tabular} & \begin{tabular}{|l|l|} 
E & $1991.1 \sim 2000.12$ \\
\end{tabular} & 31.1 & 気象台 \\
\hline 那羁 & $26^{\circ} 12^{\prime}$ & \begin{tabular}{l|l}
$N$ & $127^{\circ} 41^{\prime}$ \\
\end{tabular} & \begin{tabular}{l|l|l|} 
E & $1991.1 \sim 2000.12$ \\
\end{tabular} & 26.7 & 気象台 \\
\hline
\end{tabular}
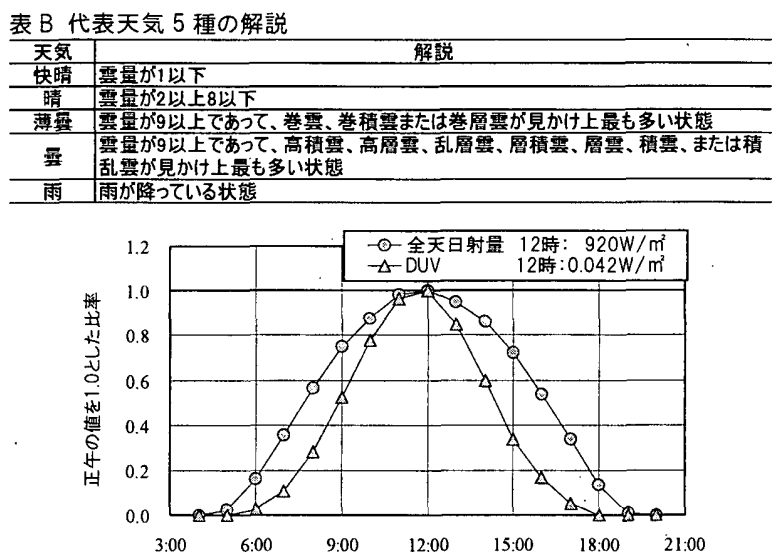

図 A 12 時の值を基準(1.0)としたDUVと日射日変動の比較 ※ 金沢 6 月の值 ${ }^{5)}$ 上り作図

文 献

1）環境省：紫外線保健指導マニュアル，2003.6 (http://www.env.go.jp/chemi/uv/uv_manual.html)

2）垂水弘夫，宮村壽，上出亘弘：紫外域日射分光観測に基づく生体影響紫外 域日射量 DUV の特性解析，日本建築学会計画系論文集，第 532 号，pp.73 $\sim 78,2000.6$

3）垂水弘夫，上出亘弘：生体影響紫外域日射DUV の雲量および簡易天気分 類に基づく解析，日本建築学会計画系論文集，第 545 号, pp.87〜92, 2001.7

4）垂水弘夫，新聖子：紫外域日射に関する許容被照時間数の地域特性解析, 日本建築学会計画系諭文集，第 554 号，pp.63～68，2002.4

5）新聖子，垂水弘夫：生体影響紫外線 DUVの時別特性解析一金沢における 紫外域日射及び気象観測データを用いて一，日本建築学会計画系論文集 第 564 号, pp.79 84, 2003.2

6）小松秀隆，竹下秀，坂田俊文，佐々木政子：晴天日の太陽 UV-B 放射の天 空輝度分布，照明学会誌，第 83 巻，第 $8 \mathrm{~A}$ 号，pp.548〜 555, 1999

7）桐生伸喜，川西利昌，井川憲男，矢口浩一：晴天空の天空紫外放射輝度分 布と柴外昼光率に関する基礎的研究，日本建築学会計画系論文集，第 540 号, pp.347 352, 2001.2

8）気象業務支援センター：大気・海洋環境観測報告 第 2 号, 2002

9）気象業務支援センター：地上気象観測原簿データ，1990〜2002

10) WHO : "Ultraviolet Radiation, Environmental Health Criteria 160", 1994 pp.231-234

11) 日本気象学会：気象科学事典, 東京書籍, 1998 